\title{
Fertility status of agriculture, forest and pasture lands of district Mansehra
}

Ayesha Riaz ${ }^{1}$, Murad Ali ${ }^{*}$, Adil Younis ${ }^{4}$, Rabia Riaz $^{5}$, Murad Ali $^{3}$, Johar $^{2}$ Raza $^{4}$, Sidra Zeb ${ }^{5}$ and Muhammad Adil ${ }^{6}$

1. Department of Soil Science, The University of Agriculture, Peshawar-Pakistan

2. Department of Horticulture, The University of Agriculture, Peshawar-Pakistan

3. Cereal Crops Research Institute Pirsabak Nowsehra, KP-Pakistan

4. Department of Plant breeding and genetics, The University of Agriculture, Peshawar-Pakistan

5. Hazara Agriculture Station, Abbottabad-Pakistan

6. Department of Agronomy, The University of Agriculture, Peshawar-Pakistan

*Corresponding author's email: Muradali75@aup.edu.pk

Citation

Ayesha Riaz, Murad Ali, Adil Younis, Rabia Riaz, Murad Ali, Johar Raza, Sidra Zeb and Muhammad Adil. Fertility status of agriculture, forest and pasture lands of district Mansehra. Pure and Applied Biology. Vol. 10, Issue 4, pp10331046. http://dx.doi.org/10.19045/bspab.2021.100108

\begin{tabular}{llll}
\hline Received: 19/10/2020 & Revised: 18/12/2020 & Accepted: 03/01/2020 & Online First: 08/01/2021 \\
\hline \hline
\end{tabular}

\section{Abstract}

Soil management practices vary with soil properties and land uses which in turn guarantee efficient utilization, economic yields and conservation of natural resources. In this context, laboratory investigations were conducted to assess the fertility status of soils distinctive for agriculture, forest and pastures in Mansehra district during 2019. Twenty soils samples from two depths (0-15 and $15-30 \mathrm{~cm}$ ) were collected from each representative land use across the district and analyzed for $\mathrm{pH}$, texture, organic matter and macro (NPK) and micronutrients $(\mathrm{Cu}, \mathrm{Fe}, \mathrm{Zn}$ and $\mathrm{Mn})$. The results showed that soils were moderately to strongly calcareous in reaction with mean higher lime in pasture followed by forest and agriculture land. All the three sites had acidic $\mathrm{pH}$ with overall mean of 6.4 and were non saline. The soils in these three locations (agriculture, forest and pastures in Mansehra) were dominantly coarse textured with relatively more in pastures than others. Soil organic matter content was relatively more in forest but was in adequate range in all sites. The soil AB-DTPA extractable $\mathrm{K}, \mathrm{Cu}, \mathrm{Fe}$ and $\mathrm{Mn}$ were also adequate in all these sites while $\mathrm{P}$ and $\mathrm{Zn}$ were dominantly deficient in all these areas. Forest soils contained relatively higher $\mathrm{P}$ and $\mathrm{K}$ but lower $\mathrm{Fe}$ and $\mathrm{Mn}$ than pasture and agricultural soils whereas there was no difference in $\mathrm{Cu}$ and $\mathrm{Zn}$ values among land uses. These results concluded that agriculture soil needs application of $\mathrm{P}$ and $\mathrm{Zn}$ for optimum crop production. Since the soils in the areas are prone to losses, thus such practices like land leveling, contour or minimum tillage, cover crops and application of organic manure are advised for soil conservation and improvement in soil properties.

Keywords: Soil fertility; Agriculture lands; Forest; Pasture lands

Introduction

It is well recognized fact that nation's economic and social wellbeing is completely dependent upon its natural resources. Among all the characteristic assets the genuine riches and the best legacy of a country is its soil. The natural forests and grasslands that existed before the landscape was modified by agricultural pursuit bear evidence to the fact that all soils throughout the world are capable 
of supporting plant, provided the climate and other factors are favorable [1]. In any case, when people established agriculture, the requirement for extra supplements is unavoidable for the most extreme yield per hectare. Cultivated crops also have different nutrient requirements than the natural plant. Many nutrients are removed from the land by the harvesting of crops. In such manner soil fertility plays an important role in crop production to satisfy the needs of our growing population and to provide raw material for the industrial sector of the country. Agreement to what it constitutes soil fertility was lacking. To some it is the amount of plant nutrients in soil, others measure it by yield capacity and still others link it in some obscure way with the activity of soil microorganisms. [2] Was the first person who put forth the view of soil fertility that plants take up simple minerals and vaporous substances and out of them manufacture complex organic compound. He likewise proclaimed that soil fertility should be maintained after the removal of nutrients from the soil by the application of manures and fertilizer. Liebig's mineral theory of plant nutrition had a profound effect on agricultural thoughts and till 1884 , soil fertility continued to be interpreted in terms of abundance of chemical nutrient elements. As the knowledge of soil science developed majority of the workers agree that soil fertility along with the combine effect of several favorable factors, including good tillage, sufficient water, aeration, soil reaction adequate organic matter, beneficial micro-organisms, available plant nutrients and crop rotation account for soil productivity. The area use frameworks including crops, tree, and pastures plays an essential part in enhancing fertility and quality of soil in a so many ways [3]. Soil fertility demonstrates the relationship between the soil and crop growth. A soil may be fertile for one harvest and not for other.
The modern and advanced soil science defines soil fertility as "the capacity of soil to supply the supplement components in the sums, structures and extents required for greatest plant growth" [4]. Most of the analysts have concentrated on the evaluation of the soil fertility of agricultural soils. Next to no consideration has been paid to forest and rangeland. The present study is intended to assess comparative fertility status of the forest, agriculture and grassland soils. This study helps in maintaining fertility status of these soils, management and improvement of the socio-economic conditions and financial status of the zone. It also forecast the chances of obtaining a profitable response to fertilizer, give sources for suggestions on the amount of fertilizer to apply and show the differences in fertility status among the soils of three different lands.

\section{Materials and Methods Site description}

The selected sampling site is located in District Mansehra of Khyber Pakhtunkhwa. The climate of Mansehra is temperate which has great influence on crop production and vegetation. The mean annual temperature $18.5^{\circ} \mathrm{C}$ and mean annual rainfall $1445 \mathrm{~mm}$. It is one of richest districts as for as forest wealth of Pakistan, comprising many large and small forests distributed all over the area. These woodlands also provide clean supply of water, wildlife, recreation and healthy environment. These forests are main source of constructional timber, large quantities of firewood and oleoresin. Furthermore they keep up the grazing requirements of millions of cattle, goats, sheep and camels. Pinus roxburghii, Poplar and Deodar are the main forest trees. Farmland is in form of terraced fields on slopes of hill as well as plain area near the river. Wheat, rice, corn, legumes, vegetables, plum, apple, apricot, walnuts are the main agricultural products of region. Pasture lands are under tremendous pressure 
of overgrazing that interns results in soil erosion.

\section{Soil sampling and preparation}

Soil testing was used as an approach for evaluating the fertility status of the soils which involves sampling and analysis. Twenty samples were collected from each site i.e agriculture, forest and pasture lands of District Mansehra. These soil samples were collected with help of auger from 0-15 and $15-30 \mathrm{~cm}$ depth. The collected samples of soil were brought to soil testing laboratory of the department of Soil and Environmental Sciences, The University of Agriculture Peshawar. These samples were air dried, grinded with wooden mallet and sieved from $2 \mathrm{~mm}$ sieve. Each sample was stored in a plastic bag which was properly labeled and was analyzed for physicochemical properties.

\section{Analytical procedures}

The different procedures were used for analytical purpose. For soil texture $50 \mathrm{gm}$ soil sample (air dried) and distilled water was taken in a dispersion cup. Then $10 \mathrm{ml}$ of $1 \mathrm{~N}$ $\mathrm{Na}_{2} \mathrm{CO}_{3}$ was added to it. The dispersion cup was then placed on the stirrer for 5-10 minutes. The dispersion cup contents were then transferred to a $1000 \mathrm{ml}$ cylinder. Readings were noted with hydrometer after 40 seconds and 2 hour for silt + clay and clay respectively. Soil texture was calculated and determined by the textural triangle [5]. Ten gram soil along with 50 milliliter distilled water was taken for soil $\mathrm{pH}$ in flask and shaken for twenty five minutes on shaker. Then electrode of $\mathrm{pH}$ meter was dipped in suspension to record the $\mathrm{pH}$ (Meclean, 1982). Total soluble salts were determined by measuring soil EC. Soil water suspension (1:5) was used to determine the EC of soil using the electrical conductivity meter [6]. To determine the soil organic matter content. One gm sample was taken into $250 \mathrm{ml}$ volumetric flask along with addition of $10 \mathrm{ml}$ (1Normal) potassium dichromate solution and 20 milliliter concentrated sulphuric acid.
Upon cooling of mixture, distilled water (200 $\mathrm{ml}$ ) was added into it followed by filtration and addition of Orthophenopthalene indicator ( 2 or 3 drops). The filtrate was then titrated against $0.5 \mathrm{~N} \mathrm{FeSO} 4.7 \mathrm{H}_{2} \mathrm{O}$ solution. Titration was stopped until the appearance of maroon color [7]. AB-DTPA Extractable Phosphorous The soil Phosphorous concentration was determined by extracting it in solution. Ten gram sample along with 20 $\mathrm{ml}$ ammonium bicarbonatediethylenetriamine pentaacetic acid solution was taken in flask. The mixture was then shaken on mechanical shaker for 15 -20 minutes followed by filtration with the help of Watt man no 42 filter paper. One ml filtrate and $3 \mathrm{ml}$ distilled water were added into volumetric flask for phosphorus determination. After that ascorbic acid mixed indicator $(5 \mathrm{ml})$ was added and made volume up to mark. Then $25 \mathrm{ml}$ flask was kept in dark for color development (blue).Along with blank and standards $\mathrm{P}$ was analyzed by spectrophotometer. AB-DTPA Extractable Potassium The Potassium content in soil was extracted in solution as done by [8] and was measured by flame photometer. AB-DTPA Extractable $\mathrm{Fe}, \mathrm{Mn}, \mathrm{Zn}$ and $\mathrm{Cu}$ Micronutrients like copper, iron, manganese and zinc were extracted through method described by [8]. Then they were analyzed with help of AAS (Perkin Elmer 2138) using acetylene gas and particular element cathode lamps.

\section{Statistical analysis}

Statistical analysis of the data was performed to calculate summary statistics for the different soil properties at significance level $(\mathrm{P} \leq 0.05)$. Different soil systems were compared using 8.1 package statistic software as described by [9].

\section{Results and Discussion Soil texture}

The percent content of clay, silt and sand of the soil samples collected from agriculture, forest and pasture land varied from each 
other. The results of (Table 1) showed that the sand content ranged from 5.2 to $66.8 \%$, 38 to $70.6 \%$ and 42 to $80 \%$ in agriculture, forest and pasture soils respectively. Soil clay content of agriculture, forest and pasture lands varied from 8 to $16.4 \%, 10.4$ to $19 \%$ and 10 to $18.6 \%$ whereas silt content ranged from 22.2 to $84.8 \%$ in agriculture, 15.2 to $48.2 \%$ in forest and 9.4 to $46 \%$ in pasture soils. The agriculture land showed great variation in texture classification i.e $50 \%$ samples of agriculture land were sandy loam, $20 \%$ were silt loam, $10 \%$ were silt, $15 \%$ were loam and $5 \%$ was loamy sand in texture .In forest texture classification, $55 \%$ soils were sandy loam while remaining $45 \%$ were loam. Whereas in pasture land texture, sandy loam was greater and dominant with $85 \%$ and $15 \%$ of soils was loam. Soil texture is intrinsic property, it may not much affected by different land uses. While variation in agriculture land could be due to rapid weathering caused by disturbance due to nonstop farming [10]. Coarse textured soil in pine forest was also reported by [11].

Table 1. Percent sand, Silt and clay

\begin{tabular}{|c|c|c|c|c|c|c|c|c|c|c|}
\hline \multirow{2}{*}{$\begin{array}{c}\text { S. } \\
\text { No. }\end{array}$} & \multirow{2}{*}{$\begin{array}{c}\text { Depth } \\
\text { (cm) }\end{array}$} & \multicolumn{3}{|c|}{ Agriculture } & \multicolumn{3}{|c|}{ Forest } & \multicolumn{3}{|c|}{ Pasture } \\
\hline & & $\begin{array}{c}\text { Sand } \\
(\%)\end{array}$ & $\begin{array}{l}\text { Silt } \\
(\%)\end{array}$ & $\begin{array}{c}\text { Clay } \\
(\%)\end{array}$ & $\begin{array}{c}\text { Sand } \\
(\%)\end{array}$ & $\begin{array}{l}\text { Silt } \\
(\%)\end{array}$ & $\begin{array}{c}\text { Clay } \\
(\%)\end{array}$ & $\begin{array}{c}\text { Sand } \\
(\%)\end{array}$ & $\begin{array}{l}\text { Silt } \\
(\%)\end{array}$ & $\begin{array}{l}\text { Clay } \\
(\%)\end{array}$ \\
\hline \multirow[t]{2}{*}{1} & $0-15$ & 38.6 & 48.8 & 12.6 & 42.6 & 38.8 & 18.6 & 42 & 46 & 12 \\
\hline & $15-30$ & 34.8 & 48.8 & 16.4 & 48.6 & 35.8 & 15 & 54 & 32 & 14 \\
\hline \multirow[t]{2}{*}{2} & $0-15$ & 26 & 60.8 & 13.2 & 50 & 31 & 19 & 64.6 & 18.8 & 16.6 \\
\hline & 15-30 & 14 & 74.8 & 11.2 & 47.2 & 34.8 & 18 & 70.6 & 14.8 & 14.6 \\
\hline \multirow[t]{2}{*}{3} & $0-15$ & 12.6 & 76.2 & 11.2 & 63.2 & 25 & 11.2 & 54.6 & 30.8 & 14.6 \\
\hline & $15-30$ & 10 & 78.8 & 11.2 & 59.2 & 30.4 & 10.4 & 50.6 & 32.8 & 16.6 \\
\hline \multirow[t]{2}{*}{4} & $0-15$ & 16.8 & 72.8 & 10.4 & 50 & 39.4 & 10.6 & 50 & 36 & 14 \\
\hline & $15-30$ & 11.2 & 78.8 & 10 & 56.4 & 32.8 & 10.8 & 54 & 36 & 10 \\
\hline \multirow[t]{2}{*}{5} & $0-15$ & 5.2 & 84.8 & 10 & 55.4 & 15.2 & 15.4 & 66.6 & 39.4 & 14 \\
\hline & $15-30$ & 9.2 & 80.2 & 10.6 & 66 & 18.8 & 15.2 & 60.6 & 23.4 & 16 \\
\hline \multirow[t]{2}{*}{6} & $0-15$ & 21.2 & 70.8 & 8 & 58 & 29.1 & 12.9 & 58.6 & 25.4 & 16 \\
\hline & 15-30 & 9.2 & 80.8 & 10 & 51 & 36 & 13 & 62.6 & 21.4 & 16 \\
\hline \multirow[t]{2}{*}{7} & $0-15$ & 30.6 & 60.8 & 8.6 & 52 & 35.5 & 12.5 & 72 & 15.4 & 12.6 \\
\hline & 15-30 & 27.2 & 62.8 & 10 & 48.8 & 42.8 & 11.4 & 74 & 15.4 & 10.6 \\
\hline \multirow[t]{2}{*}{8} & $0-15$ & 59.4 & 29.4 & 11.2 & 49 & 35.6 & 15.4 & 62 & 23.4 & 14.6 \\
\hline & $15-30$ & 58 & 30.2 & 11.8 & 38 & 48.2 & 13.8 & 68 & 19.4 & 12.6 \\
\hline \multirow[t]{2}{*}{9} & $0-15$ & 48 & 39.6 & 12.4 & 70.6 & 19 & 10.4 & 80 & 9.4 & 10.6 \\
\hline & 15-30 & 42.8 & 42.8 & 14.4 & 62.6 & 22 & 15.4 & 74 & 15.2 & 10.8 \\
\hline \multirow[t]{2}{*}{10} & 0-15 & 66.8 & 22.2 & 11 & 64.4 & 24.8 & 10.8 & 62 & 23.4 & 14.6 \\
\hline & $15-30$ & 64.8 & 25.4 & 9.8 & 68.6 & 20.8 & 10.6 & 60 & 21.4 & 18.6 \\
\hline
\end{tabular}

\section{Soil pH}

The soil $\mathrm{pH}$ varied from 5.56 to 7.26 in agriculture soil, 5.43 to 6.72 in forest and 5.23 to 8.01 in pasture soils (Fig. 1a \& 1b). The statistical analysis of data showed that when values were averaged across the depth and localities in each group, the differences in soil $\mathrm{pH}$ was not significant $(\mathrm{P} \leq 0.05)$ in these three lands. While comparing the depths, when values were averaged across the 
land use, again $\mathrm{pH}$ value was also statistically same at both the depths of $0-15 \mathrm{~cm}$ and 15$30 \mathrm{~cm}$. The majority of the soil samples were slightly acidic in nature with values between 6.0 and 6.5. The reason of acidic $\mathrm{pH}$ may be because of high OM content in these soils. The highest microbial oxidation that produces organic acids release $\mathrm{H}$ ions to the soil solution and thereby reduces soil $\mathrm{pH}$. The highest oxidation of microbes that delivers organic acids discharge hydrogen ions to soil solution and in this manner lowers $\mathrm{pH}$. Another reason might be the expansion in clay rate with profundity additionally can supply hydrogen particles from soil colloidal surfaces to the solution again diminishing which at last brings down $\mathrm{pH}$ of soil. Through filtering and waste into streams in overflow produced from quickened disintegration there might be loss of base forming cations down the soil layers, even away from sampling profundities, which in turn improves the action of hydrogen and aluminum ions in soil solution, which lessens soil $\mathrm{pH}$. Generally, $\mathrm{pH}$ values of study area come in range of moderately acidic to neutral soil reactions. Results were similar to [1215].

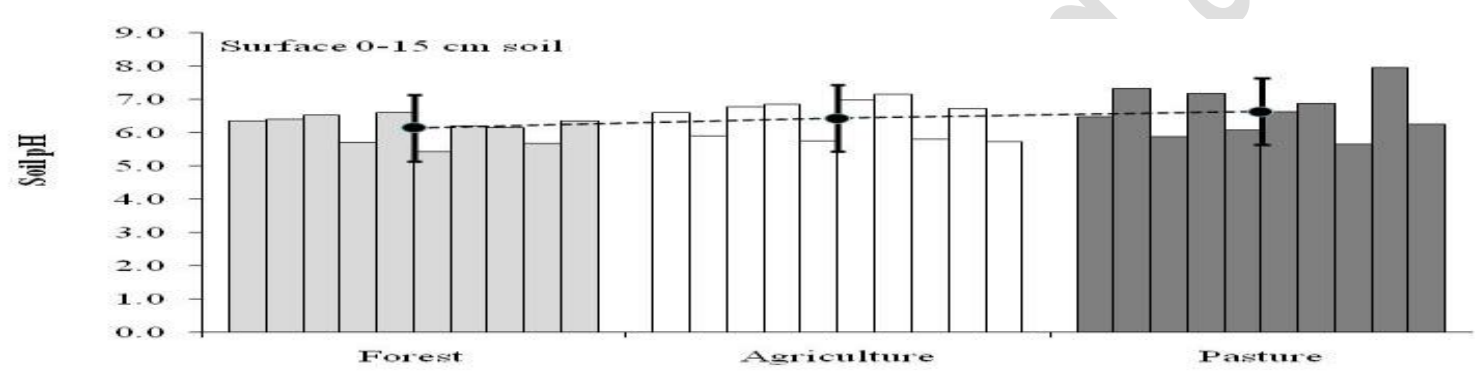

Figure 1a. Soil pH in surface soil of agriculture, forest and pasture lands

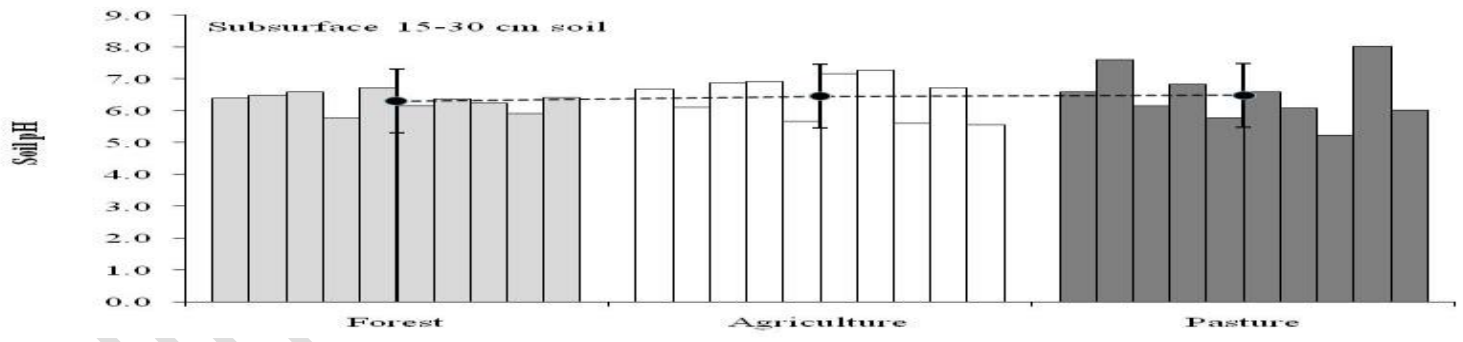

Figure 1b. Soil pH in subsurface soil of agriculture, forest and pasture lands

Soil electrical conductivity

EC of soil ranged from 0.19 to $0.62 \mathrm{dSm}^{-1}$, 0.06 to $0.72 \mathrm{dSm}^{-1}$ and 0.05 to $0.64 \mathrm{dSm}^{-1}$ in agriculture, forest and pasture soils respectively (Fig. $2 \mathrm{a} \& 2 \mathrm{~b}$ ). When averaged across the depths, there was significant difference observed in EC of these three lands. The maximum $\mathrm{EC}$ was found in agriculture soils with value of $0.42 \mathrm{dSm}^{-1}$ whereas minimum EC was found in pasture soils with value of $0.12 \mathrm{dSm}^{-1}$. While comparing the depths, when values were averaged across the land use, EC of both surface soil and subsurface soil layers was statistically same. But significantly $(\mathrm{P} \leq 0.05)$ high EC value of $0.37 \mathrm{dSm}^{-1}$ was observed in subsurface soil layer of forest as compared to surface layer which could be due to the leaching of base cations from surface to subsurface layer. Overall all the soil samples 
were non saline. [16] Also reported that variation in $\mathrm{EC}$ was negligible with depth in non-saline conditions. Amount of precipitation had great influence on soil electrical conductivity. High rainfall causes more downward movement of salts and also increase removal out of soil layers thus prevents salinity. Sandy loam texture also cause the removal of salts from soil profile.

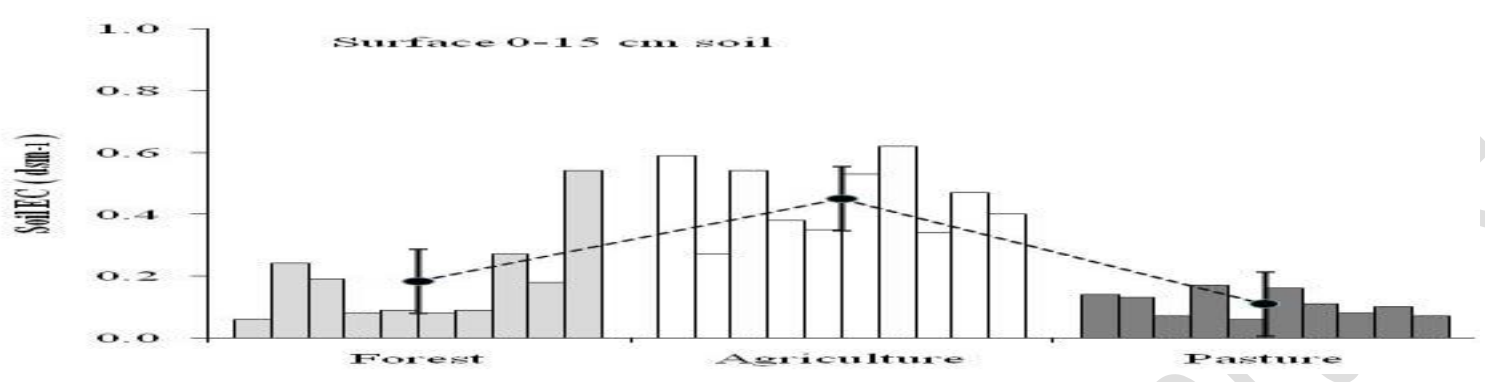

Figure 2a. Soil EC ( $\mathrm{dSm}^{-1)}$ in surface soil of agriculture, forest and pasture lands

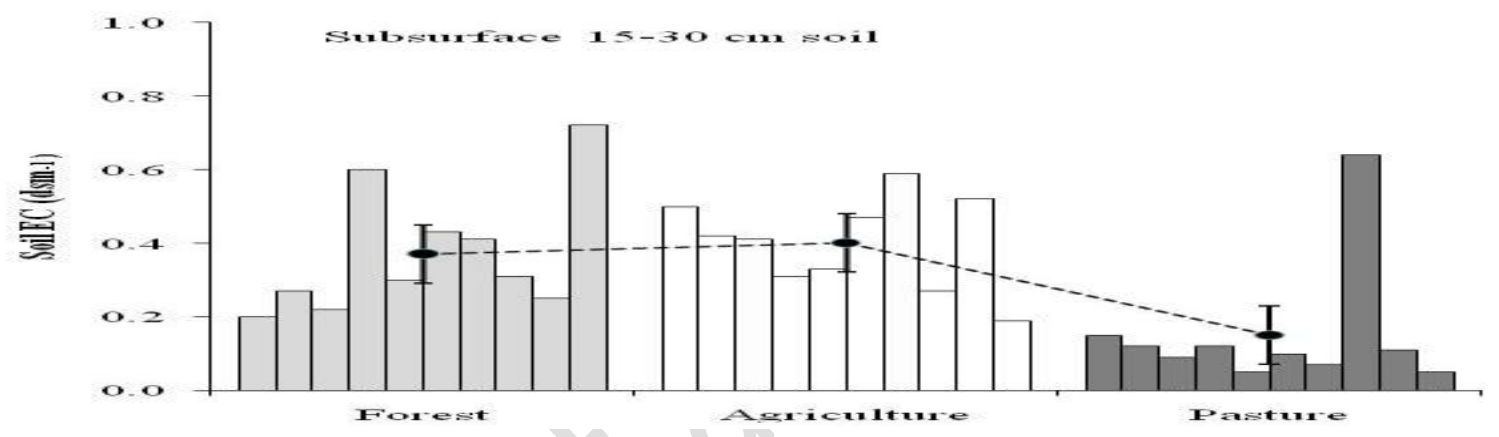

Figure 2b. Soil EC ( $\left.\mathrm{dSm}^{-1}\right)$ in subsurface soil of agriculture, forest and pasture land

\section{Soil organic matter}

The content of SOM in agriculture, forest and pasture were found to be in range of 2.13 to $4.6 \%, 1.8$ to $7.07 \%$ and 0.58 to $6.21 \%$ respectively (Fig. 3a \& 3b). The results showed that values when averaged across depth, the soil organic matter content in forest soils was $4.43 \%$ which was significantly higher $(\mathrm{P} \leq 0.05)$ than pasture and agriculture soils. The reason of maximum forest SOM is that accumulation of trees leaves, plant residues and litter material on surface soil, low temperature along with high precipitation and low decomposition rate lead to the buildup of organic matter. Low organic matter was found in agriculture soils at both depths which could be due to the harvesting of agricultural crops leaving behind very little crop residue [17]. Also tillage operations aerates the soil and break down organic residues, which results in the stimulation of microbial activity and decomposition of soil organic matter thus increased. Residue burning also reduces SOM levels by lowering the amount of residue available for SOM formation [18]. While comparing the depths, when values were averaged across the land use, the surface soil layer $(0-15 \mathrm{~cm})$ depth had significantly high $(\mathrm{P} \leq 0.05)$ organic matter content with value $4.003 \%$ as compared to subsurface soil layer $(15-30 \mathrm{~cm})$ depth with value $3.13 \%$. Our findings matched with [19], [15] and [20] who also reported the high organic matter in forest soil than agriculture and pasture. Overall 
agriculture and pasture soils were also have high amount of organic matter than those normally reported for Pakistan soil because both sites indicates that they were modified from the forest site.

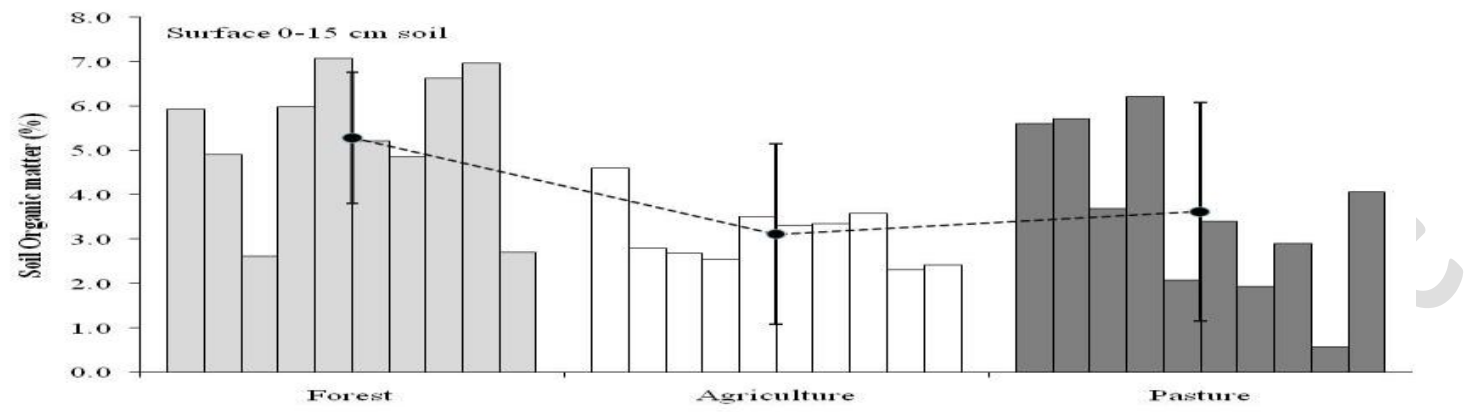

Figure 3a. SOM (\%) in surface soil of agriculture, forest and pasture lands

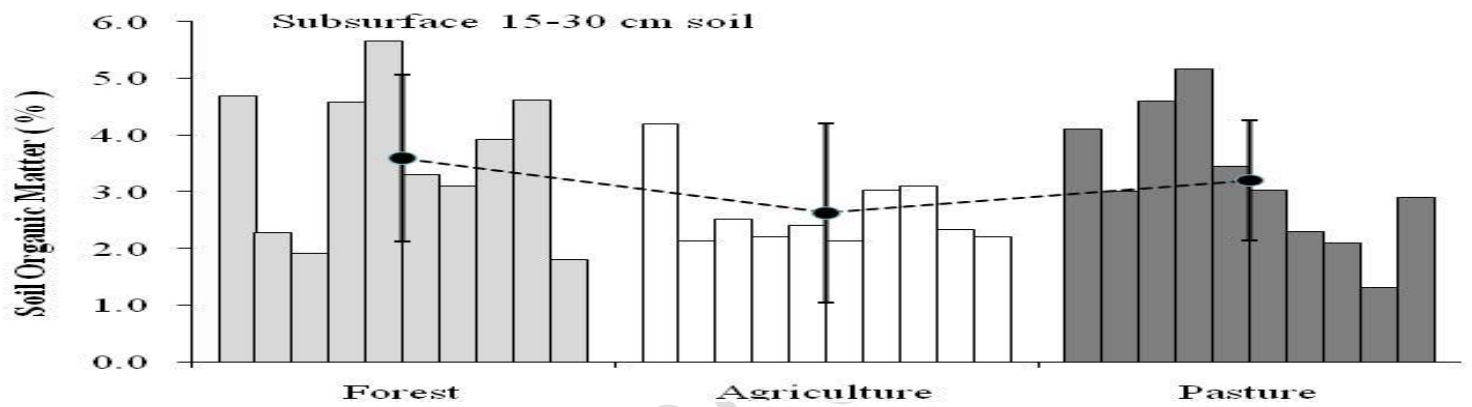

Figure 3b. SOM (\%) in subsurface soil of agriculture, forest and pasture lands

\section{AB-DTPA extractable phosphorus}

The AB-DTPA extractable phosphorus concentration varied from 1.42 to $4.6 \mathrm{mg} \mathrm{kg}^{-}$ ${ }^{1}$ in forest, 0.6 to $4.31 \mathrm{mg} \mathrm{kg}^{-1}$ in agriculture and 0.56 to $3.9 \mathrm{mg} \mathrm{kg}^{-1}$ in pasture soils (Fig. $4 \mathrm{a} \& 4 \mathrm{~b})$. When values averaged across the depth, the maximum $P$ content of $2.61 \mathrm{mg} \mathrm{kg}^{-}$ 1 was observed in forest soils followed by agriculture soils with value $2.38 \mathrm{mg} \mathrm{kg}^{-1}$ whereas minimum $P$ content of $1.85 \mathrm{mg} \mathrm{kg}^{-1}$ found in pasture soils. While comparing the depths, when values were averaged across the land use, no significant difference was observed in surface soil and subsurface soil layers. All the resulted sites were deficient in $\mathrm{P}$ concentration [21]. Low $\mathrm{P}$ in soils could be accounted as parent material and weak capacity of $\mathrm{P}$ retention .The concentration of $\mathrm{Al}, \mathrm{Fe}$ and $\mathrm{Mn}$ leach the phosphorus from surface layers to lower layers with only the fraction in organic combination remaining behind [22]. Most of the P deficiencies occur in conifer plantations on poorly drained soils. Therefore $\mathrm{P}$ deficiencies are reported more than any other nutrients [11]. Both cultivated and forest land soils had although diagnostically low but relatively higher concentration of extractable soil inorganic phosphorus than pastures [23]. The present study is concording to results of [24] and [25] who also stated high phosphorus content in forest as compared to agriculture and grassland.

\section{AB-DTPA extractable potassium}

The AB-DTPA extractable potassium concentration ranged from 69.2 to $186.6 \mathrm{mg}$ $\mathrm{kg}^{-1}, 70.3$ to $274.6 \mathrm{mg} \mathrm{kg}^{-1}$ and 51.4 to 184.4 $\mathrm{mg} \mathrm{kg}^{-1}$ in agriculture, forest and pasture soils respectively (Fig. 5a \& 5b). When the averaged across the depth, forest soils with 
value $145.81 \mathrm{mg} \mathrm{kg}^{-1}$ had significantly high $(\mathrm{P} \leq 0.05)$ potassium content than agriculture and pasture soils. The minimum $\mathrm{K}$ content of $90.71 \mathrm{mg} \mathrm{kg}^{-1}$ was found in pasture soils. While comparing the depths, when values were averaged across the land use, the surface soil layer $(0-15 \mathrm{~cm})$ depth had significantly high $\mathrm{K}$ concentration with value $129.28 \mathrm{mg}$ $\mathrm{kg}^{-1}$ as compared to subsurface soil layer (15$30 \mathrm{~cm}$ ) depth with value $104.7 \mathrm{mg} \mathrm{kg}^{-1}$. According to the criteria set by [21] none of the site was potassium deficient. Potassium appears to be abundant in most forest and agriculture soils. The element is primarily derived from micas and feldspars and occurs in soils in inorganic compounds [26]. Potassium is rapidly and efficiently recycled in forest and agriculture sites. Very little potassium appears to be leached below the root zone. Occurrence of mica and $\mathrm{K}$ feldspars had also been reported in many Pakistani soils tend to be high in available potassium $[27,28]$.

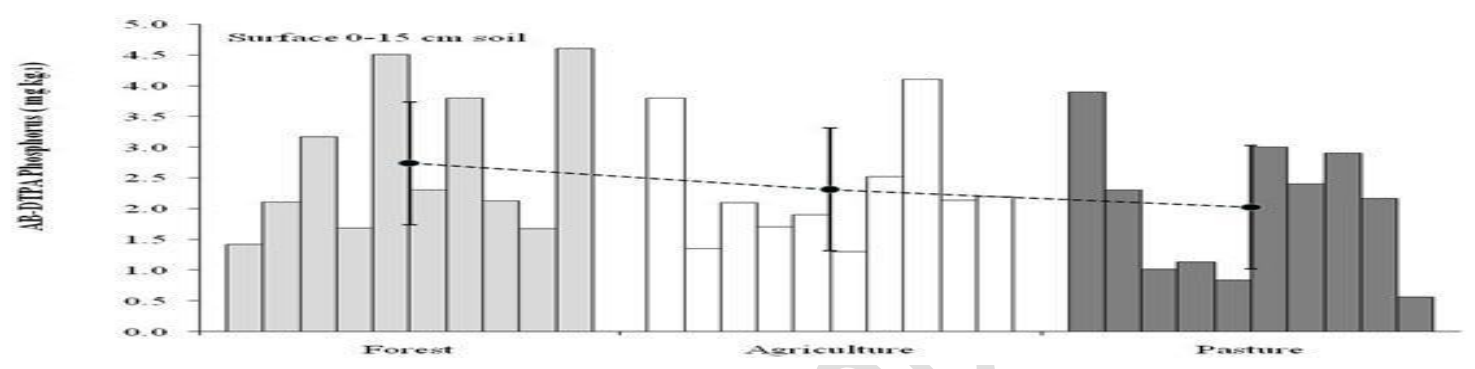

Figure 4a. AB-DTPA Phosphorus $\left(\mathrm{mg} \mathrm{kg}^{-1}\right)$ in surface soil of agriculture, forest and pasture lands

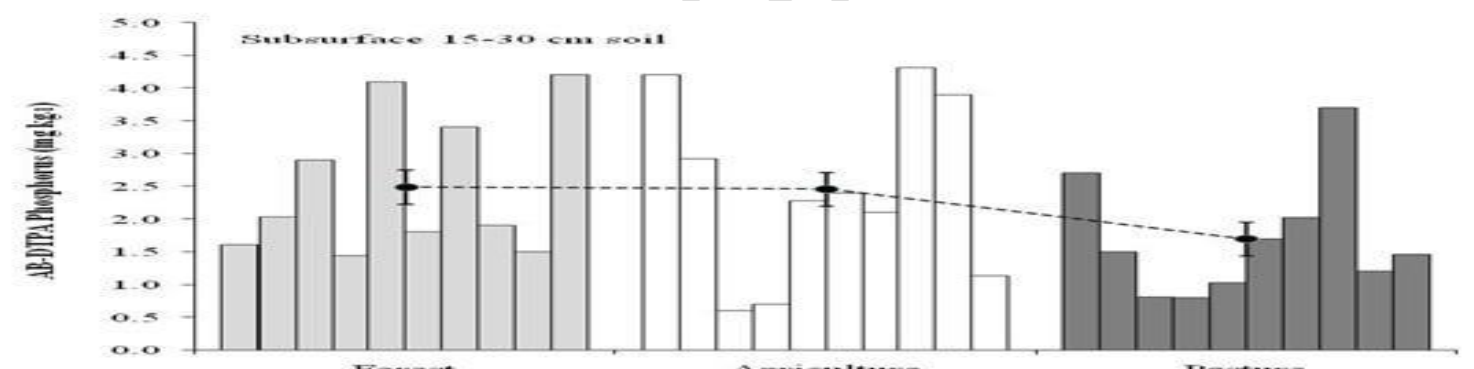

Figure 4b. AB-DTPA Phosphorus $\left(\mathrm{mg} \mathrm{kg}^{-1}\right)$ in subsurface soil of agriculture, forest and pasture lands

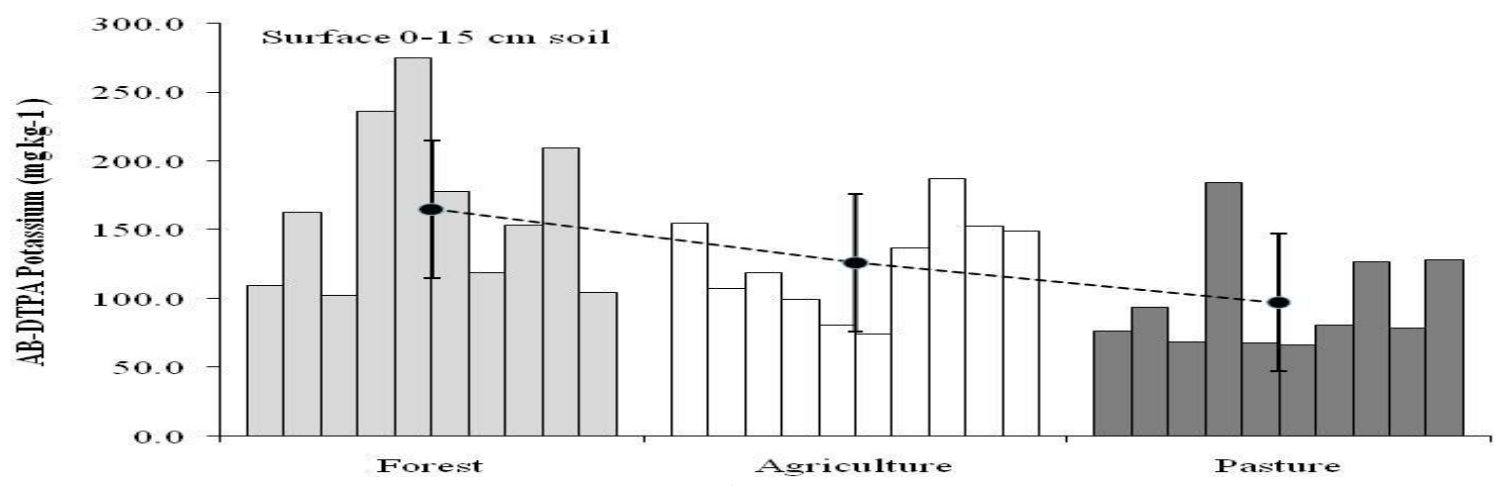

Figure 5a. AB-DTPA Potassium $\left(\mathrm{mg} \mathrm{kg}^{-1}\right)$ in surface soil of agriculture, forest and pasture lands 


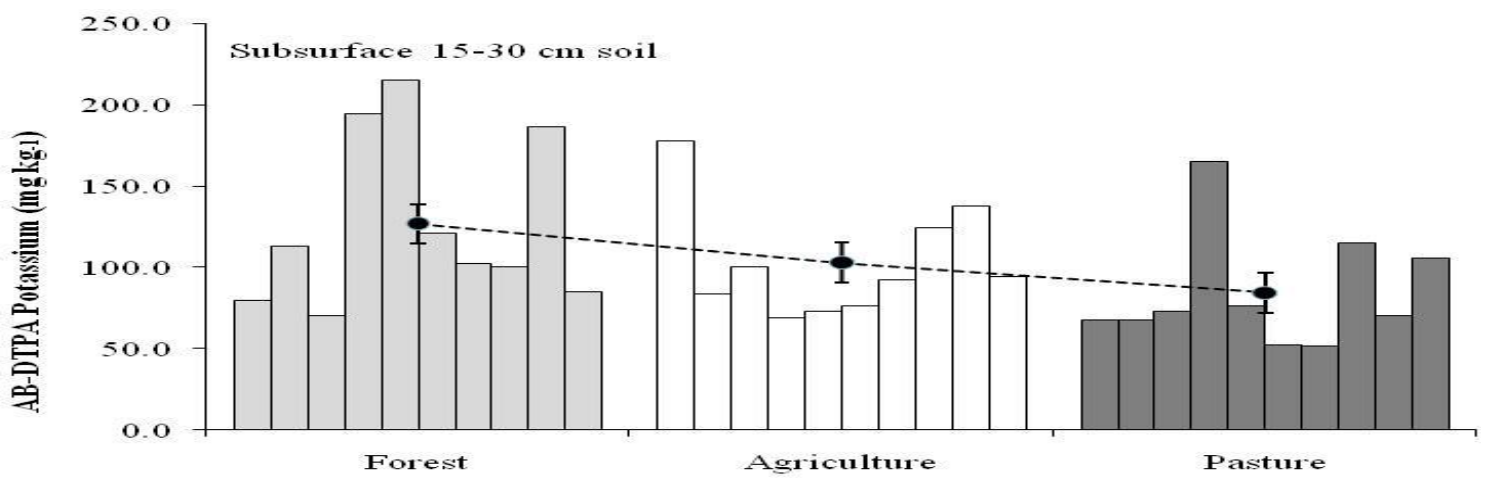

Figure 5b. AB-DTPA Potassium ( $\left.\mathrm{mg} \mathrm{kg}^{-1}\right)$ in subsurface soil of agriculture, forest and pasture lands

\section{AB-DTPA extractable manganese}

The concentration of $\mathrm{Mn}$ ranged from 0.02 to $17.2 \mu \mathrm{g} \mathrm{g}^{-1}$ in agriculture, 4.72 to $14.5 \mu \mathrm{g} \mathrm{g}^{-1}$ in forest and 0.86 to $13.04 \mu \mathrm{g} \mathrm{g}^{-1}$ in pasture soils (Fig. 6a \& 6b). The values depicted that when averaged across depth, maximum Mn content of $9.51 \mu \mathrm{g} \mathrm{g}^{-1}$ was observed in forest soil while lowest was found in pasture land. While comparing the depths, when values were averaged across the land use, at both the depths of $0-15 \mathrm{~cm}$ and $15-30 \mathrm{~cm}$, no significant $(\mathrm{P} \leq 0.05)$ difference was found. But high Mn content was recorded in surface layer of forest soils. By comparing the Mn concentration of all sites with the established criteria, [21] it was found that all the sites were sufficient in available $\mathrm{Mn}$ and no site was deficient in $\mathrm{Mn}$. [29] reported that $\mathrm{Mn}$ is found in adequate range in the soils of Khyber Pakhtunkhwa.

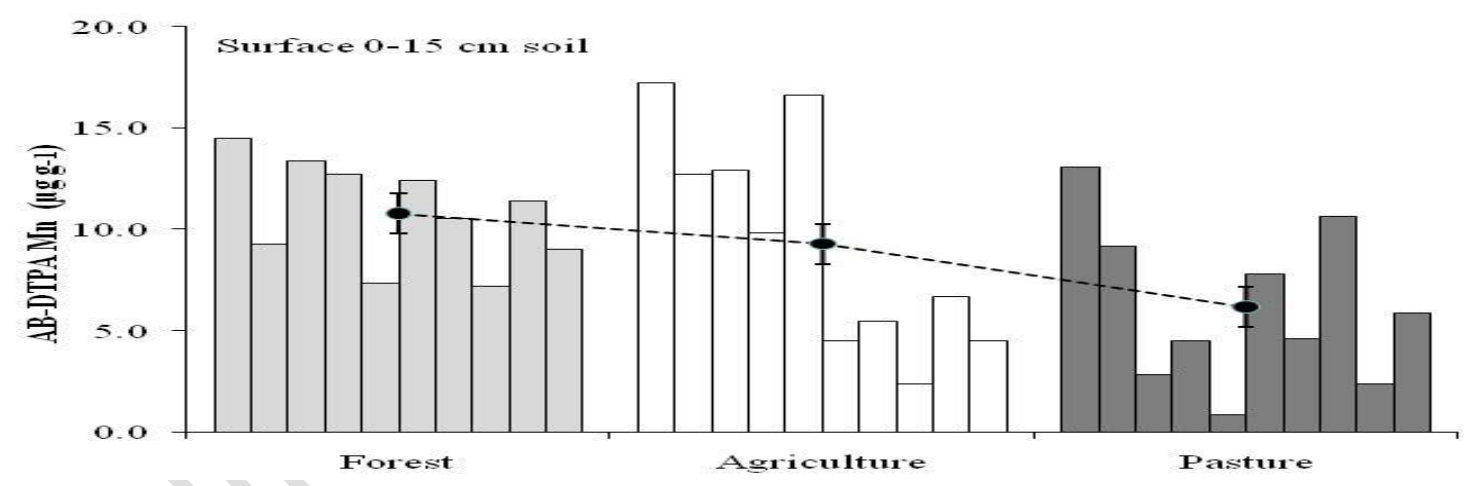

Figure 6a. AB-DTPA Mn $\left(\mu \mathrm{g} \mathrm{g}^{-1}\right)$ in surface soil of agriculture, forest and pasture lands

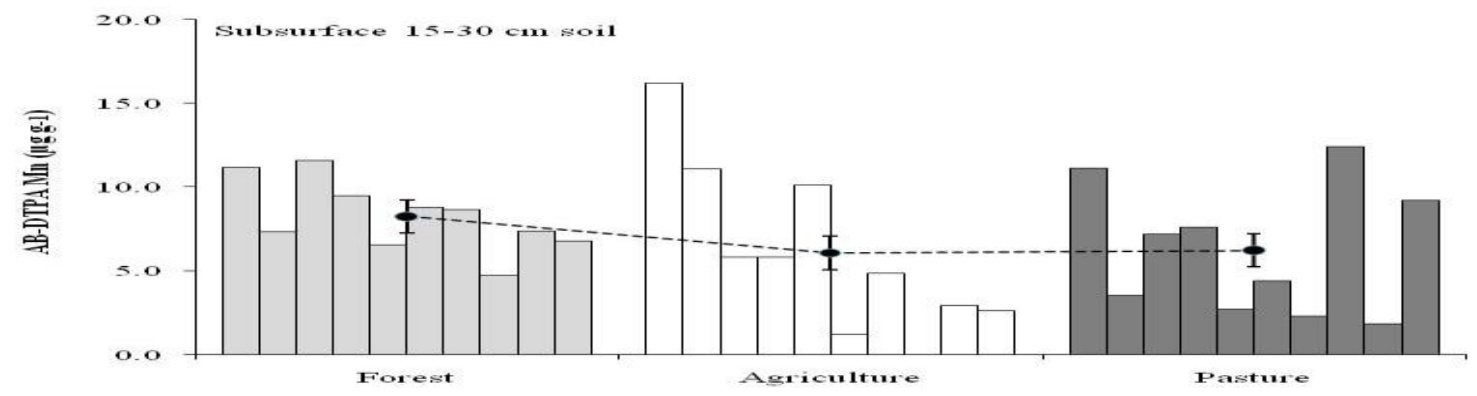

Figure 6b. AB-DTPA Mn $\left(\mu \mathrm{g} \mathrm{g}^{-1}\right)$ in subsurface soil of agriculture, forest and pasture lands 


\section{AB-DTPA extractable copper}

The results of (Fig 7a \& 7b) showed the ABDTPA extractable copper concentration in the soil sampled from forest, agriculture and pasture lands. The copper ranged from 0.7 to $2.93 \mu \mathrm{g} \mathrm{g}^{-1}$ in agriculture soil, 1.09 to $2.56 \mu \mathrm{g}$ $\mathrm{g}^{-1}$ in forest and 0.6 to $3.4 \mu \mathrm{g} \mathrm{g}^{-1}$ in pasture soil. The results showed that when averaged across the depth, there was no significant difference among forest, agriculture and pasture. While comparing the depths, when values were averaged across the land use, surface soil $(0-15 \quad \mathrm{~cm})$ depth had significantly high $\mathrm{Cu}$ content with value $1.807 \mathrm{mg} \mathrm{kg}^{-1}$ as compared to subsurface soil layer $(15-30 \mathrm{~cm})$ depth with value $1.43 \mu \mathrm{g} \mathrm{g}^{-}$ 1. The concentration of $\mathrm{Cu}$ gradually decreased with increase in depth. According to the criteria established by [21] $\mathrm{Cu}$ content was adequate in all the collected soil samples of forest, agriculture and pasture. $[30,31]$ who also concluded that $\mathrm{Cu}$ content decreased as the depth increases.

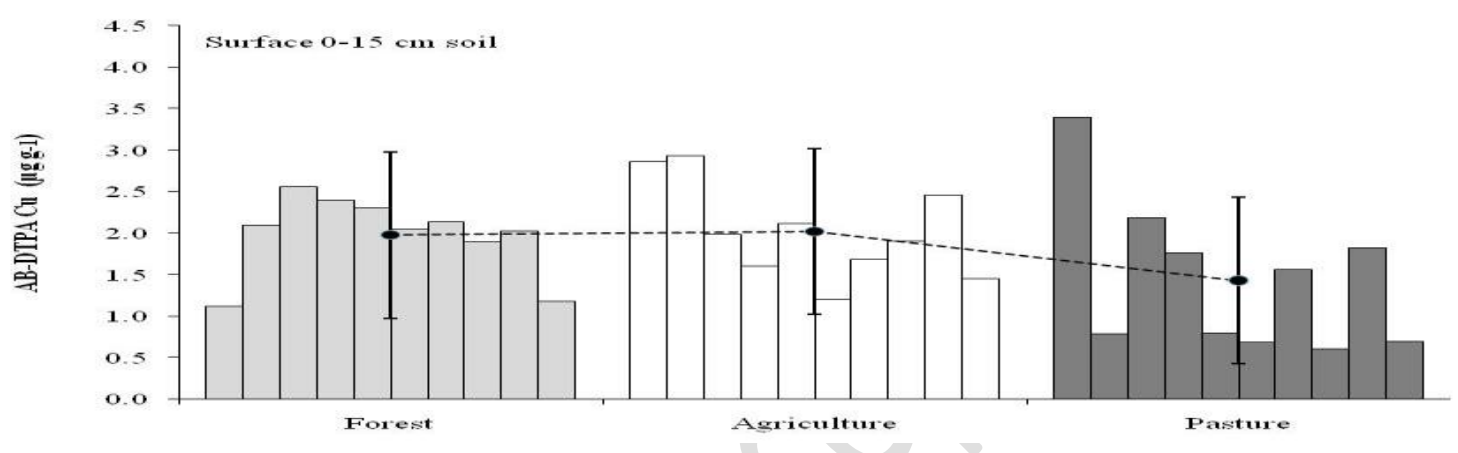

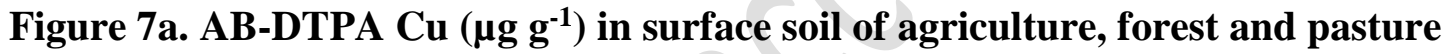
lands

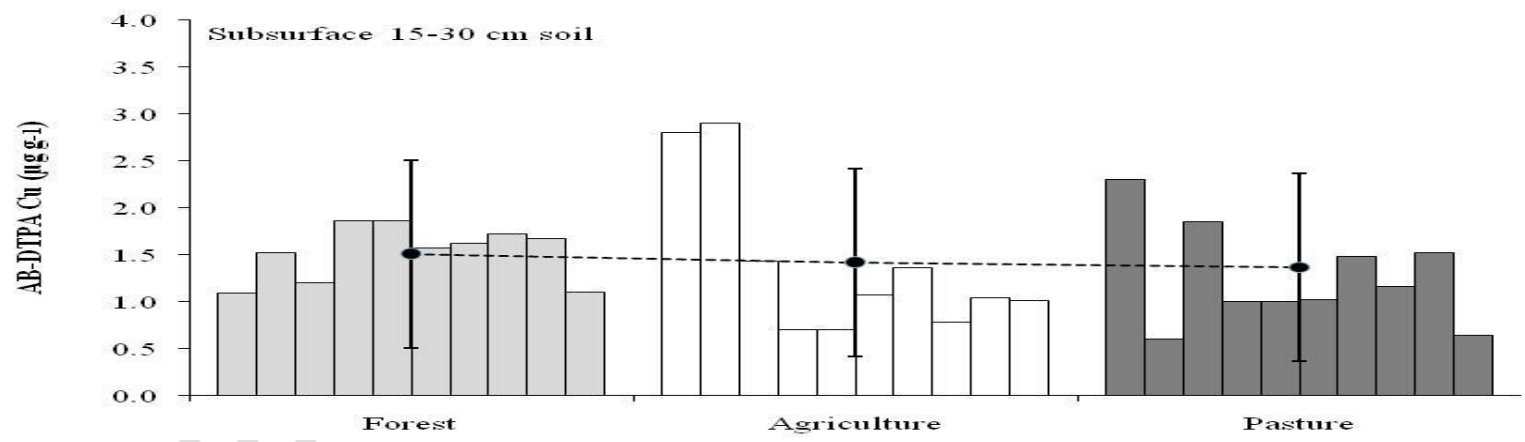

Figure 7b. AB-DTPA Cu $\left(\mu \mathrm{g} \mathrm{g}^{-1}\right)$ in subsurface soil of agriculture, forest and pasture lands

\section{AB-DTPA extractable zinc}

The concentration of $\mathrm{Zn}$ varied from 0.26 to $2.93 \mu \mathrm{g} \mathrm{g}^{-1}$ in agriculture soil, 0.43 to $2.44 \mu \mathrm{g}$ $\mathrm{g}^{-1}$ in forest soil and 0.78 to $2.78 \mu \mathrm{g} \mathrm{g}^{-1}$ in pasture soil (Fig. 8a \& 8b). When averaged across the depth, the difference in $\mathrm{Zn}$ content was non-significant in these three lands. While comparing the depths, when values were averaged across the land use, the surface soil layer $(0-15 \mathrm{~cm})$ depth had significantly $(\mathrm{P} \leq 0.05)$ high $\mathrm{Zn}$ concentration with value $1.47 \mu \mathrm{g} \mathrm{g}^{-1}$ as compared to subsurface soil layer $(15-30 \mathrm{~cm})$ depth with value $1.06 \mu \mathrm{g} \mathrm{g}^{-}$ 1. The result showed that all the three sites had marginal concentration of $\mathrm{Zn}$ [21]. The soils of Lalazar, Kaghan valley contained $\mathrm{Zn}$ 
concentration of 0.55 to $3.51 \mu \mathrm{g} \mathrm{g}^{-1}$ [32]. According to a survey about $70 \%$ of the Pakistani soils have low levels of available $\mathrm{Zn}$. After $\mathrm{N}$ and $\mathrm{P}, \mathrm{Zn}$ deficiency is the third most serious crop nutrition problem in Pakistan [33, 34]. Zinc deficiency is generally more prominent in cool wet spring season.

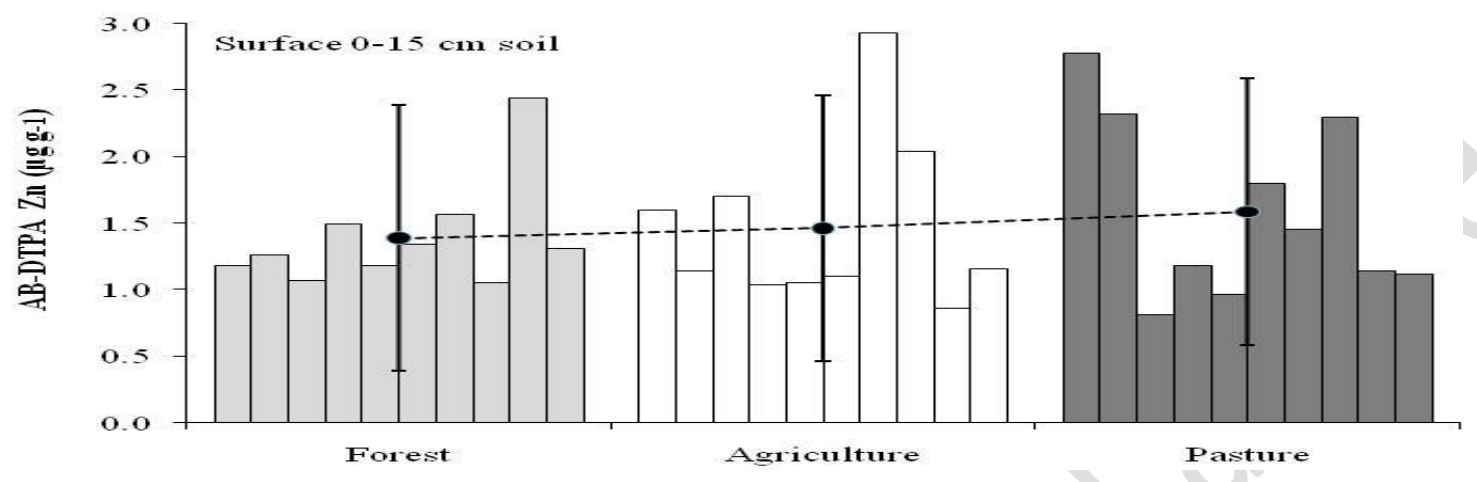

Figure 8a. AB-DTPA Zn $\left(\mu \mathrm{g} \mathrm{g}^{-1}\right)$ in surface soil of agriculture, forest and pasture lands

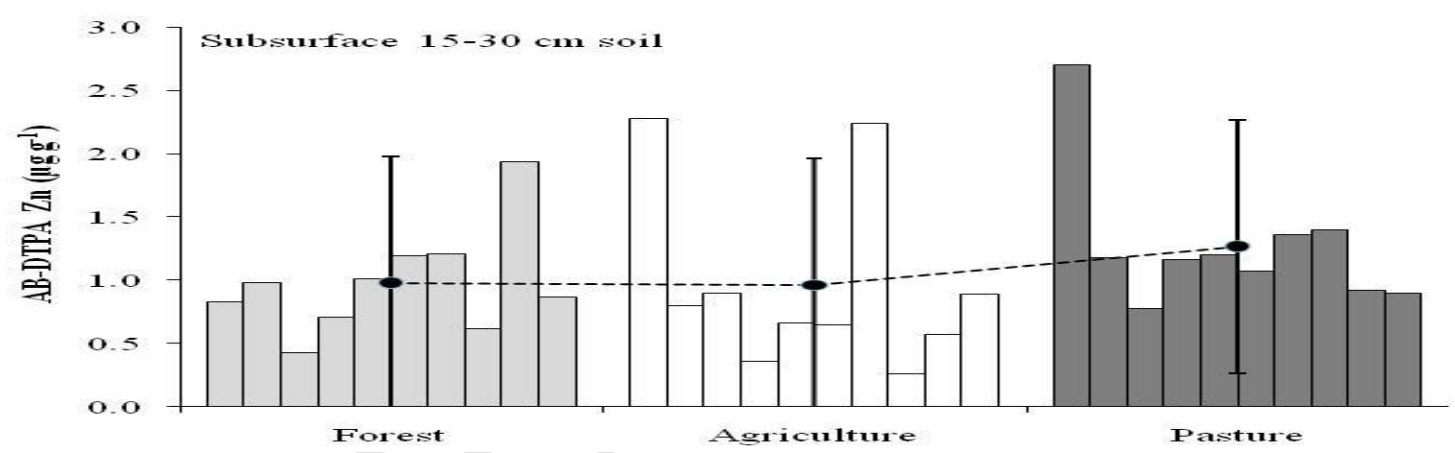

Figure 8b. AB-DTPA $\mathrm{Zn}\left(\mu \mathrm{g} \mathrm{g} \mathrm{g}^{-1}\right)$ in subsurface soil of agriculture, forest and pasture lands

\section{AB-DTPA extractable iron}

The AB-DTPA extractable Fe content ranged from 7.4 to $19.9 \mu \mathrm{g} \mathrm{g}^{-1}$ in agriculture soil, 9.4 to $22.6 \mu \mathrm{g} \mathrm{g}^{-1}$ in forest and 5.48 to $20.2 \mu \mathrm{g} \mathrm{g}^{-}$ 1 in pasture soil (Fig. 9a \& 9b). When averaged across the depth, no significant difference in $\mathrm{Fe}$ content was noted in agriculture and forest soils with value 16.72 $\mu \mathrm{g} \mathrm{g}^{-1}$ and $16.50 \mu \mathrm{g} \mathrm{g}^{-1}$ respectively but it showed maximum Fe content while lowest Fe content was observed in Pasture soil and was significantly $(\mathrm{P} \leq 0.05)$ different from forest and agriculture. While comparing the depths, when values were averaged across the land use, the surface soil layer $(0-15 \mathrm{~cm})$ depth had significantly high Fe concentration with value $17.009 \mu \mathrm{g} \mathrm{g}^{-1}$ as compared to subsurface soil layer $(15-30 \mathrm{~cm})$ depth with value $14.64 \mu \mathrm{g} \mathrm{g}^{-1}$. Iron was found abundantly in all these land based on criteria set by [21]. About 5\% of the earth's crust contains Fe and is found in all soils Bankley [35]. The findings of present study are in agreement with [13] and [36]. [37] who reported sufficient $\mathrm{Fe}$ content and also observed decrease of Fe with depth. 


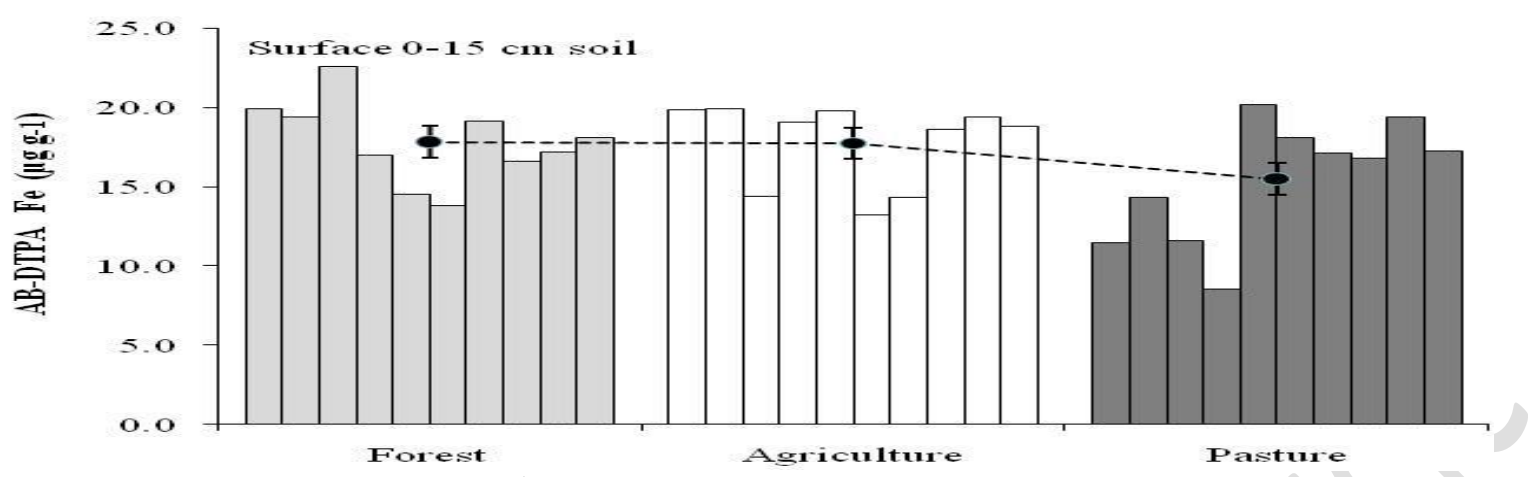

Figure 9a. AB-DTPA Fe $\left(\mu \mathrm{g} \mathrm{g}^{-1}\right)$ in surface soil of agriculture, forest and pasture lands

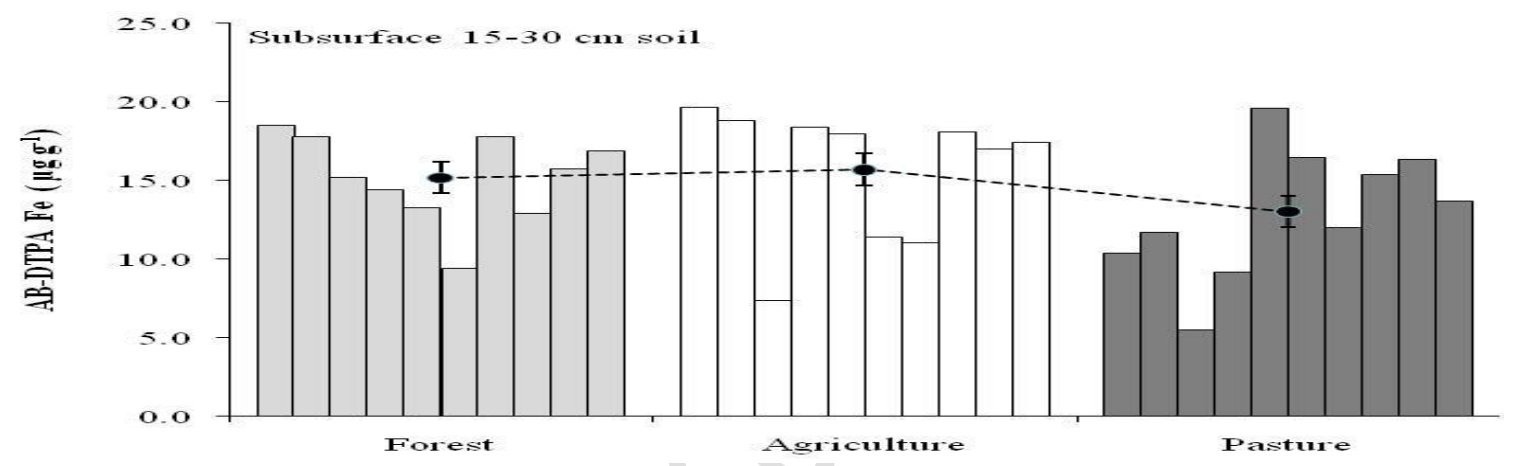

Figure 9b. AB-DTPA Fe $\left(\mu \mathrm{g} \mathrm{g}^{-1}\right)$ in subsurface soil of agriculture, forest and pasture lands

\section{Conclusion and Recommendations}

It is concluded from the experiment that all the sites were acidic in reaction and were non saline in nature. Due to predominant sandy loam structure, however, the pastured soils had lower EC than the agricultural and forest soils. All the tested soils had adequate soil organic matter which could be associated to regional soil and climatic conditions and vegetation. Relatively high organic matter content was found in forest soil as compare to agriculture and pasture soils. The ABDTPA extractable P was found low in all sites. In forest soils $\mathrm{P}$ content was relatively higher than agriculture and pasture. The soil $\mathrm{K}$ content as observed from AB-DTPA ext. $\mathrm{K}$ was found adequate in all soils. Forest had higher $\mathrm{K}$ than agricultural and pastures soils. The AB-DTPA extractable $\mathrm{Fe}, \mathrm{Mn}$ and $\mathrm{Cu}$ were in sufficient amounts whereas $\mathrm{Zn}$ was marginal in all sites. In forest soil AB-DTPA extractable $\mathrm{Fe}$ and $\mathrm{Mn}$ content was relatively higher than agriculture and pasture soils. While in case of AB-DTPA extractable $\mathrm{Cu}$ and $\mathrm{Zn}$ content, no significant difference were noted among forest, agriculture and pasture land uses. Since agriculture soils in the area are low in $\mathrm{P}$ and $\mathrm{Zn}$, so these two nutrients should be managed on priority basis. The pasture soils had also lower soil Zn and $\mathrm{P}$, and hence if possible it should be managed in these areas too. Since the soils in the areas are prone to losses, thus such practices like land leveling, contour or minimum tillage, cover crops and application of organic manure are advised for soil conservation and improvement in soil properties. 


\section{Authors' contributions}

Conceived and designed the experiments: A Riaz \& M Ali, Performed the experiments: A Riaz, Analyzed the data: J Raza, R Riaz \& S Zeb, Contributed materials/ analysis/ tools: M Ali \& A Younis, Wrote the paper: M Ali \& M Adil.

\section{References}

1. Foth HD (1984). Evaluation of Fertilizer need, "Fundamental of Soil Science." John Willey \& Sons, Inc. America.

2. Leibig V (1840) Soil fertility and productivity. In: A Rashid K S Memon (1996). Soil Sci. National book foundation Islamabad. Pakistan.

3. Nair PKR, Buresh RJ, Mugendi DN \& Latt CR (1999). Nutrient cycling in tropical agroforestory systems: Myths and science. In agroforestory sustainable agricultural Systems. 1-31. Boca Raton FL: CRC Press.

4. Ulysses \& Jones S (1982). The Soil Plant growth situation, fertilizers and soil fertility. II-ed. Reston Publishing Company, Inc. pp. 2-28.

5. Koehler FE, Moudre C \& Meneal BL (1984). Laboratory manual for soil fertility. Washington State Univ. Pulman, USA.

6. Richard LA (1954). Diagnosis and improvement of saline and alkali soils. USDA Handbook 60. Washington DC.

7. Nelson DW \& Sommer LE (1982). Total carbon, organic carbon and organic matter. pp. 539-577: In AL Page, Miller RH \& Keeny DR. (ed) Methods of Soil Analysis, Part $22^{\text {nd }}$ edition. American Society of Agronomy. Madison. World International Organization, New Delhi, India.

8. Soltanpour PN \& Schwab AP (1977). A new soil test for simultaneous extraction of macro and micronutrients in alkaline soils. Commu of Soil Sci and Plant Anal 8: 195-207.
9. Jandel Scientific (1991). Jandel Scientific Table Curve User's manual v. 3.0 software. AISN Software, Corte Madera, California.

10. Boke S (2004). Soil phosphorus fractions as influenced by different cropping systems in Andosols and Nitosols in Kembata-Tembaro and Wolayta Zones, SNNPRS. MSc Thesis. Alemaya University, (AU). pp. 131.

11. Pritchett WL \& Fisher RF (1987). Properties and management of forest soil. John Wiley and sons, Inc. USA.

12. Foth HD \& Ellis BG (1997). Soil fertility, $2^{\text {nd }}$ Edition. Lewis CRC Press LLC, USA. pp. 290.

13. Khan IA \& Khattak R (2000). Comparative fertility evaluation of agricultural, forest and rangeland soils at Hilkot watershed, Batal. District Mansehra. MSc. (Hons). Thesis. Dept. Soil Sci. NWFP. Agri. Univ. Peshawar.

14. Woldeamlak B \& Stroosnijder L (2003). Effects of agroecological land use succession on soil properties in the Chemoga watershed, Blue Nile basin, Ethiopia. Geoderma 111: 85-98.

15. Emiru N \& Gebrekidan H (2013). Effect of land use changes and soil depth on soil organic matter, total nitrogen and available phosphorus contents of soils in Senbat watershed, Western Ethiopia. ARPN J 8: 206-2012.

16. Amjad (2014). Comparative Effect of Foliar Application on Micronutrients Content in Peach Leaf and Fruit. Inter $J$ of Farming and All Sci 3(4): 382-388.

17. Bhatti AU, Rehman H \& Gurmani AH (1984). Comparative effect of potassium chloride and potassium sulphate fertilizer on the yield of paddy potash. Rev 1.

18. Maculey A (2009). Soil $\mathrm{pH}$ and organic matter. Nutr Manag Mod 8: 1-12.

19. Sanchez PA, Villachia JH \& Bandy DE (1983). Soil Fertility Dynamics after 
clearing a tropical rainforest in Peru. Soil Sci Soc of Am J. 4(7): 1171-1178.

20. Mhawish YM (2015). Effect of land use/cover change on physical and chemical soil properties within an agricultural ecosystem of Ajloun area Jordan. Inter J of Geol 5(2): 1-17.

21. Soltanpour PN (1985). Use AB-DTPA to evaluate elements availability and toxicity. Comm of Soil Sci and Plant Ana 16: 323-33.

22. Ballard R \& Pritchett WL (1974). Phosphorus retention in coastal plain forest soils: II. Significance to forest fertilization. Soil Sci Soc of Am Protocol 38(2): 363-366.

23. McGrath DA, Smith CK, Gholz HL \& Oliveira FD (2001). Effects of Land-use Change on soil nutrient dynamics in Amazonia Ecosystem.

24. Gebrelibanos T \& Mohammed A (2013). Effects of Land-Use/Cover Changes on Soil Properties in a Dryland Watershed of Hirmi and its Adjacent Agro Ecosystem: Northern Ethiopia. Inter J of Geosci Res 1(1): 45-57.

25. Takele L, Chimdi A \& Abebaw A (2014). Dynamics of soil fertility as influenced by different land use systems and soil depth in West Showa zone, Gindeberet district, Ethiopia. Agric, Fores and Fisheries 3(6): 489-494.

26. Mustanoja KJ (1965). Forest fertilization research, 1957-1964. Bot Rev 31: 151246.

27. Bajwa MI \& Rehman F (1996). Soil and fertilizer potassium. In Rashid. A., and K.S. Memon. Soil Science. National Book Foundation. Islamabad.
28. Ahmad M, Khattak RA \& Muhammad D (2008). Soil evaluation of Kafoor Dheri farm for crop production. Soil \& Environ 27: 43-51.

29. Khattak JK \& Perveen S (1985). Cooperative research programme on micronutrient status of Pakistan soils. PARC Project. KPK Agri Univ Peshawar.

30. Khattak JK, Sharif M \& Naz S (1999). Nutrient status of citrus orchard soils in Peshawar Valley. Sarhad J.

31. Tilahun G (2007). Fertility status as influenced by different land uses in Maybar areas of South Wello zone. North Ethiopia. MSc. Thesis, Harmanya.

32. Afsar M \& Khattak RA (1993). Fertility evaluation of Lalazar Soils, Kaghan Valley. MSc. (Hons). Thesis. Dept. Soil Sci. KPK Agri Univ Peshawar.

33. Rashid A, Hussain F \& Din A (1991). Nutrient status of citrus orchards in Punjab. Pak J Soil Sci 6: 25-28.

34. Rashid A (1996). Secondary and micronutrients. In: Soil Science. (Eds.): E. Saghir and R. Bantel. pp. 341-379.

35. Bankley D (1986). The context of Forest nutrition management. In Forest nutrition management. John Wiley \& Sons, Inc. America.

36. Tilahun G (2007). Fertility status as influenced by different land uses in Maybar areas of South Wello zone, North Ethiopia. MSc. Thesis, Harmanya.

37. Kiflu A \& Beyene S (2013). Effect of different land use system $n$ selected soil properties in South Ethiopia. J of Soil Sci and Environ Manag 4(5): 100-107. 